\title{
Acute angle closure glaucoma following ileostomy surgery
}

\section{Glaucoma agudo de fechamento angular após cirurgia de ileostomia}

Mariana Meirelles Lopes ${ }^{1,2}$, Ana Carolina Frota Tavares ${ }^{1,2}$, Clara Bartha de Mattos Almeida ${ }^{1,2}$, Tiffany Porraccio ${ }^{3}$, Sergio Henrique Sampaio Meirelles ${ }^{1,2}$

\begin{abstract}
Angle-closure glaucoma can be induced by drugs that may cause pupillary dilatation. We report a case of a patient that developed bilateral angle closure glaucoma after an ileostomy surgery because of systemic atropine injection. This case report highlights the importance of a fast ophthalmologic evaluation in diseases with ocular involvement in order to make accurate diagnoses and appropriate treatments.
\end{abstract}

Keywords: Ileostomy/adverse effects; Glaucoma, angle-closure/etiology; Glaucoma, angle-closure/diagnosis; Case reports

\section{ReSUMO}

O glaucoma de fechamento angular pode ser induzido por drogas que podem causar dilatação da pupila. Nós relatamos um caso no qual a paciente desenvolveu fechamento angular em ambos os olhos após injeção sistêmica de atropina. Este caso mostra a importância de uma pronta intervenção em doenças com envolvimento ocular com o objetivo de realizar o tratamento adequado.

Descritores: Ileostomia/efeitos adversos; Glaucoma de ângulo fechado/etiologia; Glaucoma de ângulo fechado/diagnóstico; Relatos de casos

\footnotetext{
${ }^{1}$ Piedade Municipal Hospital - Rio de Janeiro (RJ), Brazil ${ }^{2}$ Universidade Gama Filho - Rio de Janeiro (RJ), Brazil

${ }^{3}$ McGill University - Montreal, Canada
}

The authors declare no conflicts of interest 


\section{INTRODUCTION}

A cute angle-closure glaucoma can be induced by drugs that cause pupillary dilation, among other causes. Individuals with narrow angles, undiagnosed primary angle-closure glaucoma, shorter axial length, hyperopia, increased ratio of lens thickness to axial length and patients with shallow anterior chambers are more prone to develop angle closure ${ }^{(1)}$.

This paper reports a case of angle-closure glaucoma following ileostomy surgery ${ }^{(1)}$.

\section{Case report}

A 55 year-old white female patient was admitted to the surgery clinic to perform an ileostomy. On the fourth day after surgery, the patient developed pulsatile hemicranial headache, especially in the left temporal area, associated with ipsilateral sudden vision loss, eye pain, tearing and redness. The neurology clinic started the patient on oral steroids and indometacin as a treatment for temporal arteritis. On the sixth day after surgery, the patient remained with the same complaints and then was referred for ophthalmology evaluation.

Past medical history revealed familial poliposis, which lead the patient to surgery. Past ocular history was unremarkable. Ophthalmologic examination showed best corrected visual acuity of 20/20 in both eyes (OU). Refraction was $+1.75 /-0.5$ x150 on the right eye (OD) and $+0.25 /-1.0 \times 20$ on the left eye (OS). Moderate conjunctival congestion was seen on OS. Biomicroscopy revealed a normal reactive pupil on OD and a mid-dilated pupil with sluggish reaction on OS. Corneas were transparent and shallow anterior chambers were evident (figure 1) on OU. Gonioscopy revealed a narrow angle, visible until the Schwalbe's line (Shaffer 1) on OD and a 360 angle-closure on OS (Schaffer 0 ). Intra-ocular pressure (IOP) was $15 \mathrm{mmHg}$ OD and $40 \mathrm{mmHg}$ OS, measured with a Goldman applanation tonometry at $12: 15 \mathrm{pm}$. Fundus examination disclosed cup-to-disc ratios of $0.2 \times 0.2$ OD and $0.4 \times 0.4$ OS.

The patient chart review revealed the use of several systemic drugs such as ranitidine, intravenous atropine, midazolam, fentanyl citrate and propofol.

Based on the clinical history and physical examination, we diagnosed the patient as having an angle-closure glaucoma

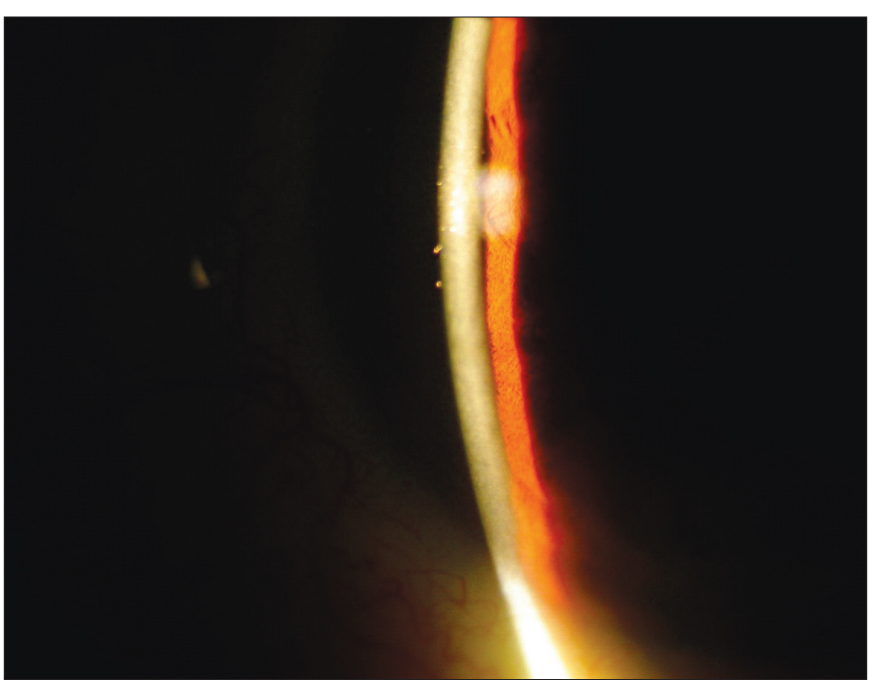

Figure 1: Narrow anterior chamber prior to the iridotomy induced by systemic medication. The previous treatment with oral steroids was interrupted and appropriate treatment was initiated with pilocarpine $2 \%$ ( 1 drop every 30 minutes), brinzolamide (1 drop OS) and timolol maleate $0,5 \%$ ( 1 drop OS). Ninety minutes later, intra-ocular pressure had dropped to $8 \mathrm{mmHg}$ on the left eye, breaking the acute crisis. An ndYAG-laser (Laserex LQP 3106, Ellex Medical PTY. LTD) iridotomy was performed on OS on the same day disclosing a wider anterior chamber right after the procedure (Figure 2) and gonioscopy revealed an open angle (Schaffer 3). Intraocular pressure was then controlled without hypotensive medication and a prophylactic laser iridotomy was performed on OD. Visual acuity remained 20/20 OU.

\section{Discussion}

There are several risk factors for angle-closure glaucoma such as Ethnicity (Eskimo, asian and hispanic), narrow angles, shallow anterior chambers, hyperopia, nanophthalmos, previous acute glaucoma attacks, family history, age, female gender, drugs with mydriatic effects and adrenergic discharge situations ${ }^{(1-6)}$.

We reported a case of angle-closure glaucoma following intestinal surgery in a 55 year-old patient with familiar polyposis.

Systemic drugs, beyond other factors inherent to the surgical procedure itself, may change the IOP and precipitate an acute angle-closure crisis or aggravate previous angle-closure glaucoma in predisposed individuals.

Several drugs can trigger this clinical picture by different mechanisms such as narrowing of the anterior chamber by pupillary dilation and/or forward movement of the iris/lens diaphragm or swelling of the ciliary body epithelium, lens or vitreous body ${ }^{(2)}$.

Next, we discuss the drugs used by the patient and their possible effects on the IOP augmentation or induction of the acute attack.

Atropine is often used to treat bradycardia related to general anesthesia. It is a parasympatholytic drug that acts by blocking the muscarinic acetylcholine receptor ${ }^{(7)}$. This effect in the eye may cause paralysis of the ciliary muscle and iris sphincter leading to mydriasis and cycloplegia, which may cause an angleclosure attack in susceptible individuals ${ }^{(8-10)}$.

Ranitidine is a histamine $\mathrm{H} 2$ receptor antagonist, used to

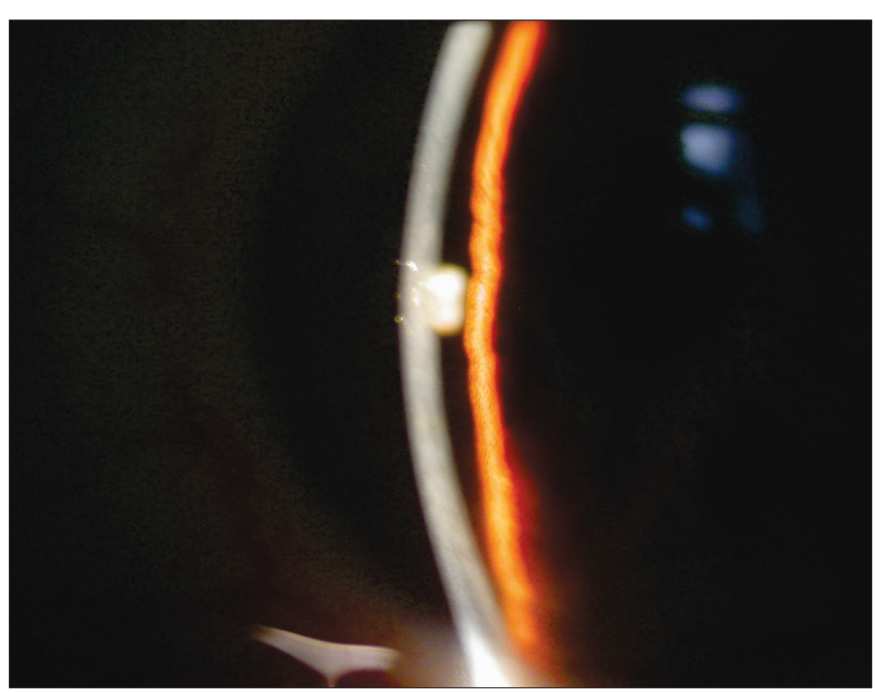

Figure 2: Enlarged anterior chamber after iridotomy 
inhibit gastric secretion. It has a weak anticholinergic effect, which can also induce pupillary dilation and acute angle closure glaucoma $^{(2,8,11-13)}$. However, so far there is no sufficient evidence that this class of drug would increase $\operatorname{IOP}^{(14)}$.

Midazolam is a benzodiazepine drug used as tranquilizer in the anesthetic induction. Some authors contraindicate the use of this drug, because of its possible anticholinergic effects ${ }^{(1)}$. A case of angle-closure glaucoma has been reported in a patient taking diazepam ${ }^{(15)}$. Betinjane et al. did not observe IOP augmentation with this medication in both normal subjects and glaucoma patients ${ }^{(16)}$.

Sedatives including propofol and fentanyl may induce pupillary dilation in toxic doses ${ }^{(8)}$.

Piridostigmina is an anticholinesterase drug used to reverse the neuromuscular blockage. Its possible ocular side effects include marked miosis, conjunctival congestion, ciliary spasm and hypertension followed by ocular hypotension ${ }^{(1,8)}$.

Angle-closure glaucoma has been previously reported in patients undergoing general anesthesia for non-ophthalmologic surgery ${ }^{(8,12,17-19)}$. Many factors may contribute to the onset of an acute angle closure attack during anesthesia in predisposed individuals: $\mathrm{CO}_{2}$ retention ${ }^{(20,21)}$; endotracheal intubation associated with laryngospasm and cough leading to IOP augmentation, and the use of anticholinergic and adrenergic drugs. Moreover, the preoperative period carries the risk of psychological stress and darkness-induced mydriasis that may increase the risk of glaucoma attacks ${ }^{(17)}$.

This case report highlights the importance of a fast ophthalmologic evaluation in diseases with ocular involvement in order to make accurate diagnoses and appropriate treatments. In this particular case, if the patient had not been correctly treated she would have ended up blind. However, in other cases a delay in treatment would cause irreversible and serious consequences. Ophthalmologist and non-ophthalmologist doctors should be aware of potential ocular side effects of systemic drugs.

Ophthalmologists should be able to identify the patients that are at risk of developing an angle crisis in order to prevent undesirable outcomes. Gonioscopy should be performed in all patients that present with shallow anterior chambers and patients with narrow angles should be aware of the side effects of certain drugs. One should always be aware of other medications used by their patients and not only care about topical drugs used in the eye. In some situations, the combination of ocular findings and the necessity of using systemic therapy is an indication for prophylactic iridotomy.

\section{RefERENCES}

1. Amêndola AC, Milani JA. Glaucoma e drogas não esteróides. In: Almeida HG, Cohen R. Glaucomas secundários. 2a ed. São Paulo: Roca; 2005. p. 251-8.

2. Tripathi RC, Tripathi BJ,Haggerty C. Drug-induced glaucomas: mechanism and management. Drug Saf. 2003;26(11):749-67. Review.
3. Salmon JF. Predisposing factors for chronic angle-closure glaucoma. Prog Retin Eye Res. 1999;18(1):121-32. Review.

4. American Academy of Ophthalmology. Glaucoma (basic and clinical science course: section 10; 2000-2001). San Francisco (CA): The Foundation of the American Academy of Ophthalmology;2000.

5. Patel KH, Javitt JC, Tielsch JM, Street DA, Katz J, Quigley HA, et al. Incidence of acute angle-closure glaucoma after pharmacologic mydriasis. Am J Ophthalmol. 1995;120(6):709-17.

6. Freedman J, Aherne A, Sinert RH. Acute angle-closure glaucoma [internet]. Medscape: New York; 2012 [cited 2007 Jun 8]. Available from: http://www.emedicine.com/emerg/topic752.htm

7. Pappano AJ, Katzung BG. Drogas bloqueadoras dos receptores colinérgicos. In: Katzung BG. Farmacologia básica e clínica. 8a ed. Rio de Janeiro: Guanabara Koogan; 2003. p. 92-104.

8. Mandelkorn RM. Nonsteroidal drugs and glaucoma. In: Ritch R, Shields MB, Krupin T. The Glaucomas. St Louis: Mosby; 1996. p. 1189-1204.

9. Schwartz H,Apt L. Mydriatic effect of anticholinergic drugs used during reversal of nondepolarizing muscle relaxants. Am J Ophthalmol. 1979;88(3 Pt 2):609-12.

10. Fazio DT, Bateman JB, Christensen RE. Acute angle-closure glaucoma associated with surgical anesthesia. Arch Ophthalmol. 1985;103(3):360-2.

11. Ates H, Kayikçioðlu O, Andaç K. Bilateral angle closure glaucoma following general anesthesia. Int Ophthalmol. 1999;23(3):129-30.

12. Lentschener C, Ghimouz A, Bonnichon P, Parc C, Ozier Y.Acute postoperative glaucoma after nonocular surgery remains a diagnostic challenge. Anesth Analg. 2002;94(4):1034-5, table of contents.

13. Dobrilla G, Felder M, Chilovi F, de Pretis G. Exacerbation of glaucoma associated with both cimetidine and ranitidine. Lancet. 1982;1(8280):1078.

14. Fraunfelder FT, Fraunfelder FW. Drug-induced ocular side effects. Boston (MA): Butterworth-Heinemann; 2001

15. Hyams SW, Keroub C. Glaucoma due to diazepam. Am J Psychiatry. 1977;134(4):447-8.

16. Betinjane AJ. Influência de derivados benzodiazepínicos na pressão intra-ocular.Tese (doutorado). São Paulo: Universidade de São Paulo;1973.

17. Lachkar Y,Bouassida W. Drug-induced acute angle closure glaucoma. Curr Opin Ophthalmol. 2007;18(2):129-33. Review.

18. Gartner S, Billet E. Acute glaucoma: as a complication of general surgery. Am J Ophthalmol. 1958;45(5):668-71.

19. Wang BC, Tannenbaum CS, Robertazzi RW. Acuta glaucoma after general surgery. JAMA. 1961;177:108-10

20. Kielar RA,Teraslinna P,Kearney JT,Barker D. Effect of changes in Pco2 on intraocular tension. Invest Ophthalmol Vis Sci. 1977;16(6):534-7.

21. Samuel JR, Beaugié A. Effect of carbon dioxide on the intraocular pressure in man during general anaesthesia. $\mathrm{Br} \mathrm{J}$ Ophthalmol. 1974;58(1):62-7.

\section{Corresponding author:}

Ana Carolina Frota Tavares

Post-Doctoral Fellow McGill University, Canada

1460, Dr. Penfield Ave, Apt 702

Montreal, QC - Canada, H3G1B8

Phone: (514)9153452

E-mail: carolafrota@gmail.com 